\author{
ks. Michał Drożḋ \\ Uniwersytet Papieski Jana Pawła II w Krakowie
}

\title{
O MEDIACH, KULTURZE I DIALOGU. RECENZJA KSIĄŻKI IN MEMORIAM ARCYBISKUPA JóZEFA ŻYCIŃSKIEGo
}

Media - kultura - dialog. W piątą rocznicę śmierci arcybiskupa Józefa Życińskiego, pod redakcją ks. Roberta Nęcka i ks. Wojciecha Misztala, Wydawnictwo Naukowe Uniwersytetu Papieskiego Jana Pawła II: Kraków 2017, 344 strony, ISBN 978-83-7438583-1, DOI: http://dx.doi.org/10.15633/9788374385848.16.

In memoriam arcybiskupa Józefa Życińskiego w piątą rocznicę jego śmierci w 2017 roku ukazała się książka zatytułowana Media - kultura - dialog. W piątą rocznice śmierci arcybiskupa Józefa Życińskiego pod redakcją ks. Roberta Nęcka i ks. Wojciecha Misztala, wydana przez Wydawnictwo Naukowe Uniwersytetu Papieskiego Jana Pawła II w Krakowie. Na początku publikacji adwokat Stanisław Kłys - jeden z inicjatorów tej publikacji i ks. Robert Nęcek - jeden z jej redaktorów napisali piękne uzasadnienie jej powstania, dając mu tytuł Arcybiskupowi Józefowi Życińskiemu in memoriam. „Upłynęło już pięć lat od przedwczesnej i niespodziewanej śmierci Arcybiskupa Józefa Życińskiego, Metropolity Lubelskiego. W miarę upływu czasu czujemy coraz bardziej i bardziej, kogo straciliśmy - Człowieka, Kapłana, Uczonego i Patriotę w najlepszym rozumieniu tego słowa - zatroskanego o los naszej Ojczyzny, poszukującego niestrudzenie sensu tego świata. Arcybiskup sens ten opierał na wierze w Boga, modlitwie, nauce oraz unikaniu irracjonalizmu, albowiem bez tego odniesienia i dbałości o niezbędną "estetykę wnętrza człowiek może być skazany do wejścia z powrotem do jaskini, w której wszystko ujdzie i wszystko jest dozwolone». Jego brak jest odczuwalny jako puste miejsce, stąd pragniemy je choć w części zapełnić, organizując ogólnopolską konferencję naukową pt. Media kultura - dialog jemu poświęconą, po to, aby spłacić dług duchowy i intelektualny, jaki wszyscy zaciągnęliśmy u niego. My, tj. Kościół Jezusa Chrystusa rozumiany przez papieża Franciszka nie jako «urząd celny», lecz «polowy szpital», i ludzie dobrej woli, mamy być wspólnotą otwartą na wyzwania naszych czasów. Uniwersytet Jagielloński, Uniwersytet 
Papieski Jana Pawła II, Akademia Ignatianum oraz Adwokatura Polska, której posłannictwo «Polsce - Wierność, Praw i Wolności Obrona, Potrzebującym - Pomoc» było mu bliskie, starają się sprostać takiemu pojmowaniu Kościoła i naukowemu opisowi świata, któremu od zawsze był wiemy Arcybiskup Józef. Arcybiskupa, który czynnie angażował się w obrony polityczne w stanie wojennym, łączyła z Adwokaturą serdeczna więź, oparta na tym samym systemie wartości, trosce o człowieka i jego niezbywalne prawa” (s. 5-6). Te słowa stanowią dobre uzasadnienie powstania tej publikacji, traktowanej jako mały znak wdzięczności dla arcybiskupa Józefa Życińskiego, in memoriam jego życia i odejścia do wieczności.

Na początku publikacji redaktorzy umieścili modlitwę arcybiskupa Józefa Życińskiego znalezioną po śmierci w jego brewiarzu. Warto ją tutaj zacytować, ponieważ oddaje ona głębię ducha tego człowieka:

Gdy budzę się rano

...budzę się rano...

mówię...

jak celnik Zacheusz

będę rozdawać,

jak Szymon

będę nosić krzyże innych,

jak Weronika

będę ocierać twarze,

jak Szczepan

dam się kamienować,

jak Jezus

na krzyżu będę przebaczać,

jak Franciszek

będę kochać.

Wieczorem spoglądam w lustro...

widzę...

Adama,

który dopiero co zjadł owoc,

Kaina,

który dopiero co zabił,

Judasza,

który dopiero co zdradził,

Piotra,

który dopiero co się zaparł,

Piłata,

który dopiero co obmył ręce,

i zasypiam

na mokrej od łez poduszce. 
A w nocy

przychodzi Jezus i pyta:

MIŁUJESZ MNIE? (s. 7-8).

Po tej części wprowadzenia redaktorzy publikują oficjalne wspomnienia, słowa pamięci, przemówienia i osobiste wspomnienia. Najpierw zamieszczono słowa powitania i pozdrowienia prof. dr. hab. med. Wojciecha Nowaka, rektora Uniwersytetu Jagiellońskiego. O wrażliwości arcybiskupa na potrzeby Stolicy Apostolskiej pisze w swoim przesłaniu kard. Gianfranco Ravasi, przewodniczący Papieskiej Rady Kultury. Duszpastersko i społecznie bardzo potrzebny, tak swoje słowa zatytułował abp Celestino Migliore, nuncjusz apostolski w Polsce. Kardynał Stanisław Dziwisz pisze o abp. Józefie Życińskim jako o człowieku Przepetnionym miłościa w myśleniu i działaniu. Ksiądz prof. dr hab. Wojciech Zyzak, rektor Uniwersytetu Papieskiego Jana Pawła II w Krakowie, pozostawia arcybiskupa z wdzięcznością w pamięci (s. 9-24).

Po tych oficjalnych tekstach redaktorzy umieścili teksty wielu autorów publikacji, którzy przyjęli zaproszenie i przygotowali na okoliczność tej publikacji swoje teksty. Stanowią one nie tylko wyraz pamięci i wdzięczności dla zmarłego abp. Józefa Życińskiego, ale są próbą uchwycenia i docenienia jego wielorakiego życiowego dzieła, które oscyluje w ramach tytułowych obszarów: media, kultura, dialog. Warto tutaj przytoczyć autorów i tytuły ich publikacji, bo wyrażają one już w tytułowych słowach kwintesencję zawartych w artykułach myśli. Ksiądz prof. dr hab. Michał Heller, laureat Nagrody Templetona pisze o Idei pola racjonalności Józefa Życińskiego. O potrzebie ochrony czci $w$ świetle wypowiedzi arcybiskupa Józefa Życińskiego pisze prof. dr hab. Andrzej Zoll. Ksiądz prof. dr hab. Wojciech Misztal wskazuje na Arcybiskupa Życińskiego koncepcję związków między duchowością chrześcijańską a mediami. Arcybiskup Józef i poe$c i$ - tę relację omawia prof. dr hab. Franciszek Ziejka. Ksiądz dr Tomasz Adamczyk analizuje Józefa Życińskiego koncepcję życia społecznego. Józef Życiński jako filozofi człowiek to tytuł artykułu prof. dr. hab. Jana Woleńskiego. Ojciec prof. dr hab. Jan Andrzej Kłoczowski OP podjął temat: Czy filozof może być biskupem? Z kolei O niedokończonym sporze z abp. Józefem Życińskim o rozumienie ludowości pisze prof. dr hab. Jerzy Bartmiński. Dialog i troska, czyli duszpasterz na wspótczesnych areopagach, tak wspomina arcybiskupa ks. prof. dr hab. Alfred Marek Wierzbicki. Poszukiwania sensu wobec postmodernizmu, relatywizmu i ironii podejmowane przez arcybiksupa omawia ks. dr hab. Michał Drożdż, prof. UPJPII. Arcybiskupa Józefa Życińskiego jako promotora mediatyzacji Kościoła przedstawia ks. dr hab. Józef Kloch, prof. UKSW. O niezłomności arcybiskupa w stanie wojennym pisze adwokat Stanisław Kłys. Język medialny jako podstawę komunikacji społecznej na podstawie studium publikacji arcybiskupa Józefa Życińskiego - omawia ks. dr hab. Robert Nęcek, zaś Duch Betanii, styl Wieczernika. Józefa Życińskiego biblijne czytanie rzeczywistości to tytuł artykułu ks. dra hab. Andrzeja Draguły, prof. US. Co z tym światem - czy musi mieć sens? Arcybiskup Józef Życiński $i$ media - ten temat podjął prof. dr hab. Wiesław Godzić. O ważnym obszarze działań arcybiskupa pisze prof. nadzw. dr hab. Ewa Kucharska: Życiński a transplantologia. Podobną tematykę medyczną podejmuje prof. dr hab. med. Tomasz Trojanowski 
w artykule Cywilizacja medialna a praktyka medyczna. Publikację zamykają wspomnienia i refleksje: najpierw brata arcybiskupa - ks. dr. hab. Wojciecha Życińskiego, prof. UPJPII, który swoją wdzięczność ujął w słowa: „ex umbris et imaginibus in Veritatem”. Na koniec przytoczono homilię ks. bp. Grzegorza Rysia wygłoszoną w czasie mszy świętej w kolegiacie św. Anny w Krakowie sprawowanej za duszę śp. abp. Józefa Życińskiego.

Publikacja ma przynajmniej potrójny walor. Po pierwsze jest znakiem i wyrazem skromnej wdzięczności dla abp. Józefa Życińskiego za jego osobę i jego dzieło. Po drugie jest próbą pogłębionej refleksji naukowej nad wieloma aspektami jego życia i działania. I po trzecie ma walor dokumentacyjno-wspomnieniowy, zatrzymując w pamięci jego osobę i inspirując do myślenia nad jego dziełem.

I na koniec tych słów recenzji podzielę się własnymi wspomnieniami o śp. abp. Józefie Życińskim. Pozostanie on w mojej pamięci jako człowiek, który się spalał; sam mówił, że szkoda czasu na to, aby się w życiu tlić, trzeba się spalać - i sam tak żył. Spalał się w szerokim spektrum swoich prac naukowych, pasterskich, ludzkich. Kiedyś podarował mi książkę o czasie, mówiąc przy okazji, że czas jest nieodwracalny, że czas nie wraca i że trzeba go dobrze wykorzystać. Tylko wieczność jest aczasowa. Te słowa zainspirowały mnie nawet do tematu pracy doktorskiej na temat nieodwracalności struktury czasu: przeszłość-teraźniejszość-przyszłość. Wszystko jest w naszej teraźniejszości, bo wspominamy arcybiskupa w naszej teraźniejszości w czasie przeszłym, ale czerpiemy z jego życia wiele pięknych momentów do naszej przyszłości. Tylko teraźniejszość jest nam dana, bo przeszłość i przyszłość są w ręku Boga.

Arcybiskup był człowiekiem wielkiego umysłu i wielkiego serca: $z$ jednej strony członek i działacz wielu towarzystw naukowych, $\mathrm{z}$ drugiej strony człowiek wrażliwy na ludzką biedę, na potrzeby studentów, na różne ludzkie duchowe i materialne biedy, wrażliwy na drugiego człowieka. Miał on tę umiejętność przechodzenia ze świata akademickiej dyskusji do rozmowy z dziećmi, z chorymi i potrzebującymi. Jego troską było wychowanie młodego pokolenia w dobie wyzwań cywilizacji medialnej. Dzień przed śmiercią referował w Kongregacji Wychowania Katolickiego projekt dokumentu o roli internetu w formacji kleryckiej i kapłańskiej. Jego troską była ewangelizacja współczesnej kultury, przenikanie jej duchem ewangelii, chodziło mu nie tylko o obecność wartości chrześcijańskich w kulturze, ale o ewangelizację kultury. Jako członek Papieskiej Rady Kultury tak widział nową ewangelizację.

Arcybiskup troszczył się o autentyczną, prawdziwą mądrość. Prawdziwa mądrość to taka, która widzi sens, która widzi cel, która widzi wartości, która przekłada się na mądre życie. „Mądrość ta pozostanie jedynie karykaturą mądrości, jeśli nie będzie znaczyć praktyki naszego życia. Mądrość pozwala odkrywać prawdziwe i nieprzemijające wartości: prawdę, dobro i piękno. Wśród tych wartości winny znaleźć się także: godność osoby ludzkiej, wolność, miłość bliźniego, sprawiedliwość, solidarność, tolerancja” - takie słowa czytamy w jego Elementarzu ${ }^{1}$. Arcybiskup Józef Życiński podejmował odważny dialog ze współczesnymi tendencjami kulturowo-cywilizacyjnymi, obecnymi przede wszystkim w dyskursie filozoficznym, ale również w przestrzeni współczesnej kultury

${ }^{1}$ J. Życiński, Elementarz księdza Życińskiego dla biskupa i świeckiego, teksty wybrał i ułożył T. Kunz, Kraków 2002, s. 109-110. 
medialnej. Potrafił on wykorzystać potencjał mediów w dziele ewangelizacji, chociażby w diecezji tarnowskiej założył radio i wydawnictwo, a w Polsce założył Katolicką Agencję Informacyjną. Potrafił także demaskować fałszywe stereotypy, odkrywać błędne ścieżki destrukcyjnych poglądów, odważnie występując w mediach z przesłaniem wartości w kontekście różnych spraw społecznie, kulturowo i ewangelizacyjnie ważnych. Był rzeczywiście człowiekiem obecnym w przestrzeni medialnej, co narażało go na różne oceny, może czasem bardzo krytyczne. Niezależnie jednak od tej różności potocznego wartościowania jego medialnej obecności warto i należy docenić trafność jego analiz i diagnoz współczesnych tendencji obecnych i promowanych w kulturze medialnej.

W kontekście myśli, które przedstawiono w recenzowanej publikacji, w oparciu o moje doświadczenia i spotkania $\mathrm{z}$ arcybiskupem chcę powiedzieć, że abp Józef Życiński, zaangażowany badawczo w obszar nauki, filozofii i teologii, uczył nas potrzeby solidnej metodologii w badaniach naukowych i otwierał na bogactwo świata ludzkiej racjonalności. Warto czerpać od niego inspirację i dobry metodologiczny klucz do korzystania z bogactwa refleksji współczesnej filozofii i metodologii nauki.

Od niego można się także uczyć życzliwego otwarcia na współczesne media i czerpać inspirację do odkrywania i pokazywania ich ludzkiego i personalistycznego oblicza. Jego odkrywcze i krytyczne diagnozy procesów i trendów współczesnej kultury medialnej i nowoczesnych prądów myślenia uczą krytycznego spojrzenia na drogi współczesnej kultury i współczesnych mediów, potrzeby racjonalnego dialogu we wszystkich obszarach ludzkich poszukiwań prawdy i dobra.

Jego odważne demaskowanie zaściankowości i postaw ekskluzywizmu oraz pokazywanie bzdur i mitów współczesnego myślenia lub jego całkowitego braku odsłania wartość i potrzebę racjonalności we wszystkich obszarach ludzkiego zaangażowania w odkrywanie sensu wartości i celu, także w kontekście współczesnych relatywizmu i ironii. „Istnieje pewna sfera obiektywnych ludzkich wartości, których nie jest w stanie usunąć żaden przełom deklarowany czy to przez media, polityków, czy filozofów. Świat, w którym brakłoby pojęcia prawdy, wierności czy altruizmu, byłby światem nieludzkim, nawet gdyby entuzjaści nowego ładu upatrywali w nim zalążków nowej ludzkości" 2 . Niech te słowa śp. abp. Józefa Życińskiego w kontekście współczesnego medialnego kultu bożków zabrzmią jako wołanie o potrzebę myślenia i potrzebę prawdziwych wartości.

\footnotetext{
${ }^{2}$ J. Życiński, Elementarz księdza Życińskiego dla biskupa i świeckiego, dz. cyt., s. 41.
} 